\title{
Sulphur behaviour and oxygen fugacity variation in Mt. Etna system revealed by melt inclusions
}

\author{
EMANUELA M. GENNARO ${ }^{1}$, GIADA IACONO- \\ MARZIANO $^{2}$, ANTONIO PAONITA ${ }^{3}$, YVES \\ MOUSSALLAM $^{4}$, NIAL PETERS ${ }^{5}$, MICHEL PICHAVANT ${ }^{6}$ \\ AND CAROLINE MARTEL ${ }^{2}$ \\ ${ }^{1}$ Università G. D'Annunzio \\ ${ }^{2}$ Institut des Sciences de la Terre d'Orléans - CNRS \\ ${ }^{3}$ Istituto Nazionale di Geofisica e Vulcanologia - Sezione di \\ Palermo \\ ${ }^{4}$ Lamont -Doherty Earth Observatory, Columbia University \\ ${ }^{5}$ University College London \\ ${ }^{6}$ Institut des Sciences de la Terre d'Orléans \\ Presenting Author: emanuelagennaro@live.it
}

It has long been recognized that melt inclusions (MIs) have the potential for providing insight into how magmas and their volatiles evolve during cooling and crystallization.

We analysed $\mathrm{H}_{2} \mathrm{O}, \mathrm{CO}_{2}, \mathrm{~S}$ and $\mathrm{Cl}$ contents of olivine-hosted MIs in several eruptive products of Mt. Etna (Italy), together with their major element composition, and iron speciation $\left(\mathrm{Fe}^{3+} / \Sigma \mathrm{Fe}\right)$. Using these data, we investigated fractional crystallization, degassing and redox conditions variations occurring during magmatic ascent.

MIs have composition extending from volatile-rich picrobasaltic toward volatile-poor evolved trachybasalt. The picrobasaltic MIs are extremely enriched in $\mathrm{H}_{2} \mathrm{O}$ and $\mathrm{CO}_{2}$ (up to 5.9 and 0.58 wt.\% respectively). S content in Etnean MIs ranging from some ppm up to more than $4000 \mathrm{ppm}$, whereas the oxygen fugacity $\left(f \mathrm{O}_{2}\right.$, estimated using XANES $\mathrm{Fe}^{3+} / \Sigma \mathrm{Fe}$ ratios and oxybarometers models) ranges from $\mathrm{NNO}-0.9 \pm 0.1$ to $\mathrm{NNO}+1.6 \pm 0.2$, with $\mathrm{NNO}$ being the Nickel-Nickel Oxide buffer [1].

Based on (i) S concentration and (ii) oxygen fugacity estimates in MIs, and using an empirical model predicting the variation of $\mathrm{S}$ partitioning between fluid and melt phases $\left(D \mathrm{~S}^{\text {fluid/melt }}\right)$ upon variations in $\mathrm{P}, \mathrm{T}$ and $f \mathrm{O}_{2}$, our research suggests that during magmatic ascent in the Etnean system a $f \mathrm{O}_{2}$ decrease occurs, affecting the $\mathrm{S}$ behaviour.

The empirical $D \mathrm{~S}^{\text {fluid/melt }}$ model coupled to MELTS code [2,3] provides evidence of $f \mathrm{O}_{2}$ decrease during volatile exsolution and crystal fractionation of olivine, clinopyroxene, spinel and plagioclase, upon $\mathrm{T}$ and $\mathrm{P}$ decrease. The $f \mathrm{O}_{2}$ diminution is responsible for the increase in $D \mathrm{~S}^{\text {fluid/melt }}$, and thus the decrease of $\mathrm{S}$ solubility in the melt and, consequently, for the increasing exsolution of $\mathrm{S}$ (which further enhances the reduction of $f \mathrm{O}_{2}$ ) from the magma before eruption.

\section{References}

[1] Gennaro, Paonita, Iacono-Marziano, Moussallam, Pichavant, Peters \& Martel (2020), Journal of Petrology, 61, 10. [2] Ghiorso \& Sack (1995), Contribution to Mineralogy and Petrology, 119, 197-212. [3] Smith \& Asimow (2005), Geochemistry Geophysics Geosystems 6, Q02004. 